\title{
Who Consents? Competing Pivots in Federal Judicial Selection
}

\author{
David M. Primo University of Rochester \\ Sarah A. Binder George Washington University and the Brookings Institution \\ Forrest Maltzman George Washington University
}

\begin{abstract}
The salience of judicial appointments in contemporary American politics has precipitated a surge of scholarly interest in the dynamics of advice and consent in the U.S. Senate. In this article, we compare alternative pivotal politics models of the judicial nominations process, each capturing a different set of potential veto players in the Senate. We use these spatial models to guide empirical analysis of rejection patterns in confirmation contests for the lower federal courts. Using data on the outcomes of all nominations to the U.S. Courts of Appeals and the U.S. District Courts between 1975 and 2006 , we show that models incorporating the preferences of the majority party median and the filibuster pivots best account for confirmation patterns we observe at the appellate and trial court levels, while advice and consent for trial courts has more recently been influenced by home-state senators.
\end{abstract}

tudents of American politics have applied considerable energy in recent years to explaining the politics of advice and consent under the U.S. Constitution. Spatial models of advice and consent have offered an analytically precise way to think about the impact of senators' and presidents' policy preferences on the selection and confirmation of presidential appointees. ${ }^{1}$ For those studies that examine appointments to the federal courts, most models treat the Senate as a unitary actor governed by the Senate median or focus on a particular veto player within the chamber. ${ }^{2}$ These studies often find that accounting for the preferences of an additional pivot beyond the Senate median can be consequential for our understanding of confirmation outcomes.

Formal Senate rules and informal practices, however, extend blocking authority to a wide range of senators beyond the Senate median and a single other pivotal senator. When the Senate considers nominations to the federal bench, formal and informal rules dictate that nominees must secure the consent of multiple potential veto players-including committee and party medians, as well as home-state senators for the court vacancy and the senators capable of sustaining a filibuster against confirmation. In this article, we seek a richer theoretical understanding of the forces that shape confirmation contests, elaborating competing spatial models that incorporate the preferences of pivotal players in isolation as well as in different combinations. We apply the lessons of our theoretical findings to confirmation outcomes for the U.S. Courts of Appeals and the U.S. District Courts between 1975 and 2006. We find that rules and practices that endow majority parties with agenda-setting advantages in executive session and that require supermajorities to cut off debate are most consequential for explaining patterns of confirmation outcomes over the past three decades. These veto powers typically outstrip the informal

David M. Primo is assistant professor of political science, University of Rochester, Harkness Hall 333, Rochester, NY $14627-0146$ (david.primo@rochester.edu). Sarah A. Binder is professor of political science at George Washington University and a senior fellow at the Brookings Institution, 1775 Massachusetts Ave. NW, Washington, DC 20036 (sbinder@brookings.edu). Forrest Maltzman is professor of political science, George Washington University, 440 Monroe Hall, 2115 G St. NW, Washington, DC 20052 (forrest@gwu.edu).

The authors wish to thank Shelly Goldman, Eric Lawrence, Keith Krehbiel, Larry Rothenberg, and Chuck Shipan for comments and advice, and Matt Jacobsmeier, Alan Murphy, and Molly Reynolds for research assistance.

${ }^{1}$ The array of recent studies include Bailey and Chang (2003), Chang (2001), Jacobi (2005), Moraski and Shipan (1999), and Nokken and Sala (2000).

${ }^{2}$ Studies that highlight the Senate median include Krehbiel (2007) and Moraski and Shipan (1999). Studies that isolate the impact of a particular veto point include Caldeira and Wright (1998), Cameron, Cover, and Segal (1990), Epstein et al. (2006), Jacobi (2005), Johnson and Roberts (2005), and Rohde and Shepsle (2007).

American Journal of Political Science, Vol. 52, No. 3, July 2008, Pp. 471-489

(C) 2008, Midwest Political Science Association

ISSN 0092-5853 
powers held by home-state senators, except for trial courts in the modern era, encouraging a more nuanced portrait of the dynamics of advice and consent for the lower federal courts.

\section{Existing Models of Advice and Consent}

In most interbranch bargaining models of the appointments process, the range of acceptable nominees is determined by the relative ideological locations of the Senate median, the president, and the status quo ideology or policy of the relevant court or agency. For example, Moraski and Shipan (1999) present a model of Supreme Court appointments that specifies the conditions under which presidents are likely to be strategic in selecting appointees. Presidential strategies are determined by the location of the Senate and Court medians, with the relative influence of each depending on the alignment of preferences among the president, Court, and Senate. Works focusing on appointments to executive agencies often posit a similar calculation: presidents are variably constrained by the Senate median, depending on the alignment of preferences between the agency, president, and Senate (e.g., Nokken and Sala 2000).

More recently, scholars of advice and consent have sought to incorporate into their models the preferences of institutional actors beyond the Senate median. One strain of such research asks whether the Senate's Rule 22 (a formal standing rule that requires supermajorities to cut off debate on the Senate floor) is consequential for the fate of judicial nominees. Johnson and Roberts (2005) and Rohde and Shepsle (2007), for example, provide formal treatments of the impact of the filibuster pivot on Supreme Court appointments and confirmation. In contrast, Jacobi (2005) proposes a model in which one of the two home-state senators for each lower court appointment can exploit senatorial courtesy to block appointments in their state. ${ }^{3}$ Conditional on the distribution of senators' intensity of interest in the judgeship, Jacobi argues that the president is compelled to select a nominee whom the home-state senator prefers to the status quo.

We seek to improve upon existing spatial accounts of the appointments process. Similar to these accounts, we are interested in the impact of Senate institutional arrangements on confirmation outcomes. Our approach differs from earlier studies in two consequential ways.

\footnotetext{
${ }^{3}$ Although most accounts of senatorial courtesy suggest that courtesy was originally extended only to senators from the president's party (Chase 1972), over the course of the twentieth century courtesy has been granted to home-state senators regardless of their party affiliation (Goldman 1997).
}

First, instead of articulating a model that highlights the impact of one Senate veto player, we propose alternative spatial models that incorporate the effects of multiple and potentially competing Senate pivots-assessing their impact in isolation and in different configurations. By comparing competing models, we are able to identify whose support among potential pivots is essential for determining the likelihood that a nominee will succeed or fail in the Senate. Second, we assess the relative ability of the models to account for empirical regularities in judicial selection by bringing to bear three decades of data on confirmation outcomes for nominations to the federal courts. ${ }^{4}$

In the models below, potentially competing pivots are defined by the rules and practices of the Senate that distribute procedural advantages to different legislative players. First, we model the impact of the chamber median. Once a nominee is called up for consideration on the Senate floor and secures an up-or-down vote, the preferences of the Senate median determine the outcome. Second, we model the impact of the majority party median, given the majority party's ability to control the agenda of the Senate Judiciary Committee and the Senate's executive session-the procedural venues in which judicial nominees are considered. ${ }^{5}$ Third, we incorporate the preferences of the senators endowed under the chamber's Rule 22 with the ability to sustain a filibuster. Because nominations can be filibustered once they are called up in executive session, the support of the filibuster pivot may be crucial for a nominee to secure an up-or-down vote. Fourth, given the Senate Judiciary Committee's practice of soliciting the views of the two home-state senators for each nomination (via the committee's "blue slip" practice), we explore whether the blue slip grants senators a veto over whether to confirm nominees slated for judgeships within their home states. ${ }^{6}$ Finally, we consider the

${ }^{4}$ Others have offered empirical analyses of confirmation outcomes (Binder and Maltzman 2002, Caldeira, Hojnacki, and Wright 2000, Martinek, Kemper, and Van Winkle 2002, and Moraski and Shipan 1997). In contrast to these efforts, we base our empirical analysis on alternative spatial models that allow us to determine the impact of multiple veto players on confirmation outcomes.

${ }^{5}$ Because the motion to go into executive session is nondebatable (and thus cannot be filibustered), the majority party through its floor leader wields control over the executive session agenda. On majority party procedural powers, see Cox and McCubbins (2005); on the influence of Senate party leaders, see Smith (2005).

${ }^{6}$ The blue slip is an informal practice used by the Judiciary Committee to solicit the views of the two home-state senators (regardless of party) about the nominee before the panel reaches a decision on how to proceed with the nomination. We treat the blue slip as a formal right and then evaluate the fit of such a model to data on confirmation outcomes. While we treat the blue slip as a formal right in our model, in practice the blue slip is not included in the formal rules of the Senate or the Judiciary panel. 
ability of the Judiciary Committee median to block a nomination, even if it cannot formally prevent consideration of a nomination on the Senate floor.

Because these institutional arrangements are not mutually exclusive, we assume that there are multiple points at which a nomination could be blocked from securing a confirmation vote. Thus, the models below explore the impact of the institutions in isolation as well as in 11 different configurations, including a model that allows all pivots to exercise a veto. The upshot of the 16 possible configurations is a simple but important result: the most extreme pivots have the potential to exercise the greatest blocking power in confirmation contests. Senators' ability to block confirmation appears to be contingent on how the rules of the game distribute power in the chamber and on the senators empowered by Senate rules for each nomination.

\section{The Models}

To capture the full range of institutional and party-based forces that may shape confirmation outcomes, we solve 16 confirmation gridlock models. In each of the models, let judicial ideology be represented by a one-dimensional policy space. ${ }^{7}$ The status quo court ideology is represented by $q .{ }^{8}$ There are 100 senators with symmetric, single-peaked preferences and ideal points $x_{i}, i \in\{1,2$, $3, \ldots, 100\}$, where senators are ordered from left to right

${ }^{7}$ A multidimensional model would add significant complexity with little additional analytical value. For instance, Hammond and Hill (1993) explore a two-dimensional model of appointments to administrative agencies featuring five committee members, and their results are qualitatively similar to the comparable models in our article. Moreover, as we explore in note 23, second-dimension issues such as race and civil rights that might arise in a confirmation battle typically align on the first dimension during the time period studied here.

${ }^{8}$ There are different ways to view the status quo ideology of a court, as well as the impact of a judicial appointment on the ideological composition of a court. Identifying the Court median during a Supreme Court term and the impact of a vacancy is relatively straightforward (e.g., Krehbiel 2007); the concept and importance of the status quo for the multicourt federal bench is more complicated, given that appellate court cases are usually heard by randomly drawn three-judge panels that may not include the newly appointed judge. Of course, the likelihood that a nominee will shift the court composition is greater with a divided court, even when three-member panels are drawn. We set aside these issues and assume that the effect of a judicial appointment is to move the court's ideology from the status quo to some other point on the one-dimensional policy space. This is sufficient for all the results that follow in the article, both formal and methodological; how the status quo is defined does not impact the results. For a more detailed discussion of the importance of judicial status quo points, see Hammond, Bonneau, and Sheehan (2005); for evidence that senators, organized interests, and presidents understand the relevance of the status quo, see Ruckman (1993). based on ideology. Preferences are common knowledge. Let $m=x_{50}$ denote the ideal point of the Senate median if the president is to the left of the ideological spectrum, and let $m=x_{51}$ if the president is to the right. ${ }^{9}$ The filibuster pivots, or senators who may be crucial to a nominee's success in the event of a filibuster, are $f_{1}=x_{41}$ and $f_{2}=x_{60} .{ }^{10}$ The President has an ideal point denoted $p$ and the median of the maJority party has ideal point $j .{ }^{11}$ The Senate Judiciary Committee has an ideal point denoted by $c$.

For each nomination assume that there are two homestate senators with ideal points $h_{1}$ and $h_{2}$, where without loss of generality $h_{1}<h_{2}$. The identity of the home-state senators varies by judicial vacancy. For instance, each seat on the federal appellate bench is historically associated with a particular state. Thus, when the president seeks to fill a vacant "California seat" on the $9^{\text {th }}$ Circuit Court of Appeals, the two senators from California are the homestate senators for the vacancy. Although presidents have at times attempted to redesignate the home state for a vacancy, such efforts are rarely successful. ${ }^{12}$

Each of the 16 models posits a president and specific legislators who are pivotal in the confirmation process: a median voter model, in which the president must satisfy the median voter; a majority party model, identical to the median voter model, but adding a majority party median who can act as a veto player or gatekeeper (Cox and McCubbins 2005), blocking an unacceptable nominee; a filibuster model, in which the president must ensure that his nominee secures the support of the filibuster pivots; a blue slip model, ${ }^{13}$ in which the president must secure the support of both home-state senators for a nomination (as

${ }^{9}$ Because tie votes are broken in the Senate by the vice president, 50 votes are sufficient for a nominee to be confirmed, but 51 votes against are required to kill a nomination. If the president is to the left, then the fiftieth senator is pivotal. If she supports the president, then the nomination is successful. The same logic holds if the president is to the right.

${ }^{10}$ The number of votes required to invoke cloture and end a filibuster is determined by the Senate's Rule 22. For the period studied here, the threshold to end debate is constant at 60 votes.

${ }^{11}$ When there is an even number of majority party legislators, it is possible that no legislator will be located at the median majority party ideal point, which may be the average of two ideal points. In presenting the formal theory, we assume an odd number of majority party members.

${ }^{12}$ Senators Barbara Mikulski and Paul Sarbanes in 2003, for example, objected to the president's effort to shift a 4th Circuit seat from Maryland (represented by two Democrats) to Virginia (represented by two Republicans; Dewar 2003). Sarbanes threatened a filibuster, and the nomination was killed by inaction; the candidate was not renominated in the following Congress.

${ }^{13}$ Our model differs from Jacobi's (2005). Her model grants veto authority to only one home-state senator. Also, her model assumes that nominees can be confirmed by the Senate even if a majority of senators oppose the nomination. In contrast, we incorporate the ideal points of both home-state senators, as well as that of the 
well as the median voter); a committee model, in which the president must secure the support of the median member of the Judiciary Committee as well as the Senate median, and 11 additional models incorporating all permutations of the above. ${ }^{14}$ Considering 16 different models enables us to assess the conditions for successful appointments to the federal bench-an approach that allows us to examine the conditions under which the support of particular pivots is required for securing confirmation.

In all cases, the president proposes a court composition to the Senate by proposing a new member to the court. If a nominee is approved, then the court composition shifts accordingly. If a nominee is rejected, then the court composition remains at the status quo $q .{ }^{15}$ Whether each senator will support or oppose confirmation depends on the utility the senator receives when judgeships remain vacant. Let $u_{i}(q)=-\left|x_{i}-q\right|$ represent the utility of seeing the court remain at $q$ and $u_{i}(y)=-\left|x_{i}-\mathrm{y}\right|$ represent the utility of seeing the court add a judge that yields a court composition/ideology $y .{ }^{16}$

chamber median. Senator Orrin Hatch (R-Utah), briefly chair of the Senate Judiciary Committee in 2001 (and again in 2003-2004), announced modifications to the committee's blue slip policy, suggesting that a single positive blue slip would be sufficient to proceed with a committee hearing on a nominee. (Given a Republican president, the modification was intended to prevent a single Democratic home-state senator from blocking confirmation.) However, Hatch appears to have made exceptions to his own policy; some nominees went forward even when both home-state senators registered objections to the nominee, and some nominees stalled on the threat of Democratic filibusters. More generally, it is important to keep in mind that the chairman's blue slip "policies" are established by memoranda to the White House Counsel's office, and typically contain vague caveats such as requiring "sufficient" White House consultation with home-state senators in determining whether or not to respect an objection of a home-state senator. By incorporating the preferences of both home-state senators, we are modeling the received understanding of the blue slip practice over most of the period studied here.

${ }^{14}$ The chamber median is excluded from all models with the filibuster since the median will always be located between the two filibuster pivots and thus cannot affect the outcome.

\footnotetext{
${ }^{15}$ Alternatively, the president could potentially make at least a shortterm change in the status quo composition of the court by making a recess appointment to the bench; under the Constitution a recess appointee can serve until the end of the next session of Congress. Recess appointments thus allow the president to circumvent a veto by one of the Senate's pivotal players. Indeed, this is precisely the dynamic that explains why President Bush made two recess appointments to the Courts of Appeals in 2004. Facing intractable Democratic filibusters of his two nominees, the president used his recess appointment authority to place the nominees on the bench (Stolberg 2004). Still, the president's recess appointment authority should not affect bargaining in the future to a great degree, since the Senate knows that at the end of the next session the judgeship will become vacant again.
}

${ }^{16}$ Nonspatial factors might also affect a senator's desire to keep a seat vacant (e.g., an approaching presidential election or a divided
Only the key decision makers change from model to model. The number of rounds of bargaining will not change the model's outcomes, nor will the patience of the players, so we assume that there is just one round of bargaining (Primo 2002). ${ }^{17}$ The models build on the work of Romer and Rosenthal (1978) and Krehbiel (1998), with each of the models featuring a region of status quo points that cannot be defeated. The endpoints that anchor this gridlock interval are the ideal points of pivotal senators and/or the president, depending on the model and the preferences of key players. We are interested in learning the conditions under which the court composition cannot move from $q$. In a complete information spatial model, of course, confirmation failure should never occur. Still, others (Gerber 1999; Krehbiel 1998) have used similar setups to study the filibuster, presidential vetoes, and citizen initiatives-none of which should occur in equilibrium either.

Unlike policies, which can be chosen with precision, it will be difficult, though not impossible, to find a judge who will perfectly match the ideology of the existing court in cases in which $q$ lies in the gridlock interval. In cases in which the status quo lies outside of the gridlock interval, the same issue does not arise: there are several locations of the court that the president and the pivotal players will prefer to the status quo. For example, consider the basic median voter model. Let the president be located at 1 and the Senate median at .5. If the status quo is at .75, the only type of candidate who will be nominated and confirmed is one who keeps the status quo precisely at .75. If the status quo is at .4 , however, any nominee whose confirmation would place the court between .4 and .6 would be satisfactory since the resulting court composition would provide an improvement over the status quo from both the median voter's and the president's perspectives. Therefore, in cases in which the status quo lies within the gridlock interval, some efforts by the president to move the court away from the status quo are likely to fail. ${ }^{18}$ Nor are efforts

bench). These factors, if modeled, would simply shift the utility function by a constant for any given seat, either increasing or decreasing the size of the gridlock interval but not in systematic ways. Because we are interested theoretically in comparing the impact of Senate institutions on confirmation, we do not incorporate these forces into the models.

${ }^{17}$ Of course, this is just a simplification. In reality, the appointments process is a dynamic process with multiple rounds of bargaining and with an appointment of one judge influencing the constraints on appointments in the future. More work on the dynamic nature of judicial appointments is needed.

${ }^{18}$ To be sure, vacancies are eventually filled-whether because of the political costs of not filling the nomination, the costs imposed on the judiciary in terms of an increased workload, or other forces. These factors apply to all vacancies, not just to those in which $q$ 
by the president to select a nominee who leaves the court at the status quo guaranteed to succeed. Senators can be expected to scrutinize such appointees carefully to determine whether they are in fact status quo nominees. Such scrutiny inevitably drags out the confirmation process, making it more likely that the Senate will fail to act on a nomination before the end of the Congress (on the impact of Senate delay, see Martinek, Kemper, and Van Winkle 2002 and Shipan and Shannon 2003). Even in cases in which rejection is all but assured, the president will still make some nomination, since there is a cost to not doing so. In fact, there may be advantages to doing so, as the president can paint a Senate controlled by the opposing party as obstructionist. ${ }^{19}$

In sum, we hypothesize that the larger the gridlock interval, the more likely is any given nomination to be contentious and to fail. Intuitively, the farther apart are the relevant players, the more likely is a status quo court to be located between the two players, making any changes to its composition more likely to fail. The intuition here is consistent with Rohde and Shepsle's (2007) treatment of Supreme Court appointment politics: polarization of the political parties, which typically expands the size of the filibuster gridlock interval, should in theory make most nominations dead on arrival (absent political inducements from the president and organized groups).

For presentational ease, we do not characterize equilibrium behavior. Instead, we focus on the intuition for how one calculates the gridlock interval corresponding to each equilibrium. The concepts of Pareto optimality and a Pareto improvement will be helpful as we think about which status quo points lie in the gridlock interval. An outcome is Pareto optimal if no player can be made better off without making another player worse off. An outcome is a Pareto improvement if at least one player is made better off, relative to the status quo, and all players are at least as well off as under the status quo. A status quo point lies in the gridlock interval when it is Pareto optimal, and it lies outside of the gridlock interval when a Pareto improvement is possible.

falls in the gridlock interval. The impact of being in the gridlock interval is simply to make it more difficult to find common ground. In other words, the probability of rejection for a nominee outside the gridlock interval will always be lower than the probability of rejection for a nominee inside the interval.

${ }^{19}$ The president may also be constrained in how much he can move the status quo, given that a single appointment to a court only shifts the court ideology so much (Snyder and Weingast 2000). However, lower courts are different than the Supreme Court or even most agencies because cases are not heard en banc, but rather by a single judge or subset of judges. Therefore, every appointment has some effect on the average court ideology and may shape legal outcomes.

\section{TABle 1 Competing Pivots in Judicial Confirmation Models}

\begin{tabular}{ll}
\hline Model & Possible Pivots \\
\hline Median voter model & $\mathrm{m}$ \\
Majority party model & $\mathrm{j}, \mathrm{m}$ \\
Filibuster model & $\mathrm{f}_{1}, \mathrm{f}_{2}$ \\
Blue slip model & $\mathrm{h}_{1}, \mathrm{~h}_{2}, \mathrm{~m}$ \\
Committee model & $\mathrm{c}, \mathrm{m}$ \\
$\begin{array}{l}\text { Majority party and blue slip model } \\
\text { Majority party and filibuster model }\end{array}$ & $\mathrm{j}, \mathrm{h}_{1}, \mathrm{~h}_{2}, \mathrm{~m}$ \\
$\begin{array}{l}\text { Majority party and committee model } \\
\text { Majority party, blue slip, and filibuster }\end{array}$ & $\mathrm{j}, \mathrm{c}, \mathrm{f}, \mathrm{f}_{1}, \mathrm{f}_{2}, \mathrm{~h}_{1}, \mathrm{~h}_{2}$ \\
$\quad \begin{array}{l}\text { model } \\
\text { Majority party, blue slip, and committee }\end{array}$ & $\mathrm{j}, \mathrm{h}_{1}, \mathrm{~h}_{2}, \mathrm{c}, \mathrm{m}$ \\
$\quad \begin{array}{l}\text { model } \\
\text { Majority party, filibuster, and committee }\end{array}$ & $\mathrm{j}, \mathrm{f}_{1}, \mathrm{f}_{2}, \mathrm{c}$ \\
$\quad$ model & \\
$\begin{array}{l}\text { Filibuster and blue slip model } \\
\text { Filibuster and committee model }\end{array}$ & $\mathrm{f}_{1}, \mathrm{f}_{2}, \mathrm{~h}_{1}, \mathrm{~h}_{2}$ \\
Filibuster, blue slip, and committee model & $\mathrm{f}_{1}, \mathrm{f}_{2}, \mathrm{c}, \mathrm{f}_{2}, \mathrm{~h}_{1}, \mathrm{~h}_{2}, \mathrm{c}$ \\
Blue slip and committee model & $\mathrm{h}_{1}, \mathrm{~h}_{2}, \mathrm{c}, \mathrm{m}$ \\
"Full” model with all possible pivots & $\mathrm{j}, \mathrm{f}_{1}, \mathrm{f}_{2}, \mathrm{~h}_{1}, \mathrm{~h}_{2}$ \\
\hline
\end{tabular}

Note: The gridlock interval for each model is bounded by the left-most and right-most extreme of the possible pivots and the president.

In each of these models we assume that the rules are binding; in other words, we treat the blue slip as a perfectly enforced rule rather than a practice that could be disputed. This allows us to sidestep debates about whether judicial nominations can be subjected to a filibuster and whether the blue slip is binding. The question is whether these institutions have an impact on confirmation outcomes, and we maximize their likely impact in the models.

The gridlock interval in each model will have as its endpoints the left-most and right-most extreme of the possible pivots and the president. We illustrate this principle using an example, and then summarize the possible pivots of each model in Table 1. For example, in the majority party model, the relevant players are $p, j$, and $m$. Therefore, any change in the composition of the court must make the president, majority party median, and chamber median better off (or at least as well off). If the majority party median's ideal point is between those of the chamber median and president, then the majority party median has no impact on the outcome and the gridlock interval will be bounded by $m$ and $p$. When the majority party median is more extreme than either the president or the chamber median, then the gridlock interval will be one of the following: If $m<p<j$, then the gridlock 
interval is $[m, j]$. If $j<p<m$, then the gridlock interval is $[j, m]$. If $j<m<p$, then the gridlock interval is $[j, p]$. If $p<m<j$, then the gridlock interval is $[p, j]$. The gridlock intervals can be constructed in a similar fashion for the other models (see Table 1).

Example. Figure 1 characterizes the equilibrium outcomes for six of the models (each institutional configuration independently plus the "full" model, which includes all institutions - the filibuster, the blue slip, a majority party median, and a committee median) and one particular configuration of ideal points: $h_{1}<f_{1}<p<m<c$ $<f_{2}<h_{2}<j$, where senators are equally spaced along the policy interval from $[1,100]$, and the president is assumed to have an ideal point of 45 . Home-state senators have ideal points of 30 and 65; the Judiciary Committee median, 55 ; the majority party median, 75 . Since 1975 , the filibuster pivots have been prescribed by Senate Rule 22 at 41 and 60 . The median's location is 50 based upon simple majority rule and a left-wing president. For each of the models, we assume that the president nominates an individual who is both closest to his preferred point and makes all pivotal players at least as well off as the status quo. In other words, the president selects a nominee who is as close to him as possible and who the pivotal players would view as no worse than the status quo (and possibly better).

The $x$-axis identifies possible status quo points. Theyaxis illustrates equilibrium outcomes. The portion of the figure along the 45-degree line sloping up represents the gridlock intervals for the six models. Thus, for the median voter model, the gridlock interval contains all status quo points between the president's preferred outcome (45) and the median's (50). If the status quo is between these two points, the median would prefer the status quo to any individual whom the president is likely to nominate. The $y$-axis reveals that if the status quo is either less than 45 or greater than 55 , the outcome will be at the president's preferred point. If the status quo is between 45 and 55 , the outcome will be between $p$ and $m$ (and at $m$ if the status quo is 50). For the blue slip model, the pivotal players are the president, located at 45 , and the two home-state senators, located at 30 and 65 . In this model, the gridlock interval covers any status quo points that fall between the two home-state senators. The y-axis also indicates that the outcome will be at $p$ for a very narrow set of status quo points on the far left $(<15)$ and on the far right $(>85)$. The figure also shows that if the status quo is at $h_{2}$, the

\section{Figure 1 Comparison of Nomination Process Outcomes}

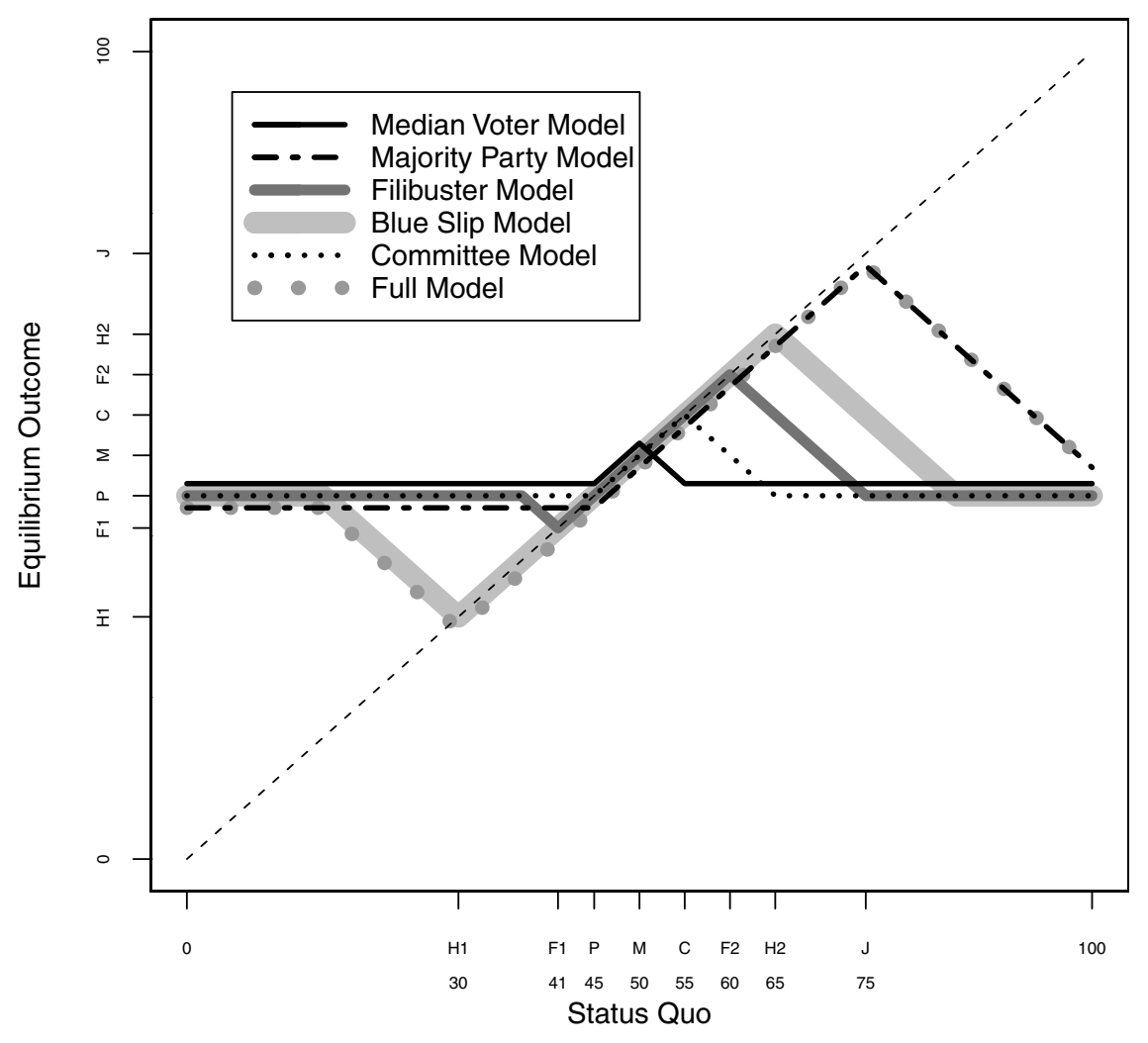


outcome will also be at $h_{2}$. This occurs because any other proposed court composition would be blocked by this pivotal senator.

The figure makes clear that for many status quo points, the models predict identical outcomes. For example, all six models predict an outcome at $p$ for status quo locations less than 15. Likewise, all six models predict no change in court ideology when the status quo is between the president and the median. In addition, both the majority party and blue slip models predict no change in court ideology for any status quo location between the president's ideal point (45) and the right-most home-state senator's ideal point (65).

Despite the overlap, the figure shows that the sizes of the gridlock intervals vary by model. And of course, it is important to remember that these are the outcomes for only one particular configuration of ideal points. If $j$ were less extreme than $h_{2}$, for instance, the gridlock intervals would change accordingly. This variation provides us with leverage that can be used to determine the degree to which expansion of the size of the gridlock interval makes confirmation less likely.

\section{Connecting Models and Data}

To understand how the models can be used to inform empirical analysis of the confirmation process, we begin with a central intuition from the models: the ideological composition of each bench cannot be changed if the existing court composition falls within the gridlock interval established by each model. Theoretically, the president could select a nominee who would leave the court composition precisely at the status quo composition, and thus the nominee should be confirmed. In practice, finding a nominee who would keep the court precisely at $q$ will be difficult. Thus, we expect that nominees will face a tough confirmation battle at least some of the time: either the Senate will drag its feet or will refuse to confirm the nominee.

Central to the data analysis is the relationship between the size of the gridlock interval and the set of status quo points for which no change in court composition can occur: the wider the interval, the larger the set of status quo courts caught within the interval. Thus, the size of the interval should be directly related to the rate of confirmation failure. ${ }^{20}$ The larger the gridlock interval, the

\footnotetext{
${ }^{20}$ To relate the size of the gridlock interval, the status quo, and confirmation success, we need to assume that the status quo is drawn from a uniform distribution. This is a relatively innocuous assumption that is common in tests of this sort. In fact, it is particularly appropriate for judicial appointments. Because court ideology changes slowly (a change in one judge has a limited im-
}

more likely is $q$ to fall in the interval, and thus the more likely rejection will occur. ${ }^{21}$

Our empirical analysis focuses on nominations to the U.S. Courts of Appeals and District Courts between 1975 and 2006. Our goal is to detect the relative strength of the different pivotal politics models in explaining patterns of confirmation outcomes in the modern era of judicial politics. We do not conduct the analysis to argue that some of these institutions are irrelevant, as surely all of them play a role, to some degree, in shaping outcomes. Rather, we are asking which models provide the best fit to observable patterns of confirmation outcomes. This approach allows us to explore the relative importance of different Senate rules and practices in shaping the course of judicial selection.

\section{Data and Method}

Dependent variable. The dependent variable indicates whether or not each nominee for the U.S. Courts of Appeals and District Courts between 1975 and 2006 was eventually confirmed in the Congress in which he or she was nominated. We code confirmation outcome as 1 if the nominee failed to be confirmed ( 0 otherwise). We draw nomination data from the final editions of the Senate Judiciary Committee's Legislative and Executive Calendar (Final Edition) published each Congress. ${ }^{22}$ Because there are no home-state senators for nominations to the D.C. Circuit (and thus no opportunities for a home-state senator to invoke the blue slip to affect the fate of those nominees), we estimate two sets of equations for each level of the courts (one including and one excluding nominations to the D.C. Circuit). The data include 367 appellate court nomination opportunities (excluding 34 nominations to the D.C. Circuit Court of Appeals) and 1,364 trial court nomination opportunities (excluding 30 nominations to the D.C. Circuit District Court).

pact on the overall bench ideology), the policy orientation of each lower court bench is unlikely to change dramatically in any given year. As a consequence, over time many different court ideologies are likely to be observed across the policy spectrum. For a similar assumption about the distribution of status quo points, see Chiou and Rothenberg (2003).

${ }^{21} \mathrm{~A}$ similar intuition applies to the length of the nomination process. Empirically, we find similar results for the entire time period when we model the duration of the nomination process rather than whether or not the nominee is confirmed. The results are weaker if we restrict the sample by time period.

${ }^{22}$ Data for the $109^{\text {th }}$ Congress are drawn from the Department of Justice's Office of Legal Policy: http://www.usdoj.gov/olp/ judicialnominations 109.htm. 
Independent variables. For each model, we use firstdimension DW-NOMINATE scores to measure the relevant gridlock interval. ${ }^{23}$ First, for each Congress and nomination, we identify DW-NOMINATE scores for the relevant home-state senators, filibuster pivots, chamber and majority party medians, committee medians, and the president. Second, using the models described earlier, we determine the relevant gridlock intervals based on the players' alignment of preferences. In the full model, the widest gridlock interval is most frequently anchored by the ideal points of the president and a home-state senator ( $49.6 \%$ of the district court cases and $45 \%$ of the appellate court cases) and the president and the majority party median (19\% of the district court cases and $20.4 \%$ of the appellate court cases). We also construct a dummy variable to denote divided control of the White House and the Senate as a means of determining whether the gridlock models offer more or less explanatory power than a divided government analysis.

Because nominee characteristics may affect the timing and outcome of confirmation contests (see Binder and Maltzman 2002; Martinek, Kemper, and Van Winkle 2002), we also craft a dummy variable to capture the quality ratings issued by the American Bar Associ-

${ }^{23} \mathrm{DW}$-NOMINATE scores are made available by Keith Poole on http://www.voteview.com. We use the version of DW-NOMINATE scores calculated after the end of the $109^{\text {th }}$ Congress (downloaded July 20, 2007). Should second-dimension preferences, which tap senators' views on racial and social issues, also be modeled? Since the 1970s, race-based issues have increasingly fallen along the first dimension (McCarty, Poole, and Rosenthal 1997, 2006). Thus, even when disputes over judicial nominees center on appointees' civil rights records, senators' positions on these appointees are typically tapped by the first dimension. To test our intuition about the lessened importance of the second dimension, we regress senators' confirmation votes for appellate court nominees between 1975 and 2006 on their first- and second-dimension DW-NOMINATE scores. For the 53 confirmation votes with sufficient variation to estimate such effects, the first-dimension score is statistically significant in 48 of the 53 models, and the second dimension is statistically significant in only one case. In four cases both dimensions are statistically significant. The one case in which the second dimension alone helps to explain variation in senators' votes was the 1979 confirmation vote for Bailey Brown, nominated by President Jimmy Carter for the $6^{\text {th }}$ Circuit. When Brown refused to resign from an all-white men's club, Senator Jacob Javits commented, "It is wrong for a judge to rule on race cases in the morning and then go to lunch at a club that discriminates by race" (Lyons 1979). Nor is it the case that the second dimension matters only for Southern senators, as the regression results do not change substantially when we add a variable that interacts a dummy for Southern senators with senators' second-dimension scores. Because the second dimension is empirically inconsequential for the vast majority of nominees who receive up-or-down confirmation votes in this period, we confine our analysis to a single dimension. See also Nokken and Sala (2000), who test the dimensionality claim using nominations data from agencies and the Supreme Court dating back to the 1950s. Only appointments in the 1950s and 1960s were shown to be influenced by a second dimension. ation. $^{24}$ The dummy variable denotes whether or not the majority of the ABA committee rating each nominee considered the nominee well-qualified. Table 2 provides summary statistics of the variables used in the analysis; Table 3 provides a breakdown of failure rates by Congress.

Estimation. The 16 gridlock intervals that constitute the models are nonnested alternatives. Thus, we estimate separate logit equations for each model and for each level of the court (Clarke 2001). To determine which gridlock interval best captures the pattern of confirmation outcomes, we compare the Bayesian Information Criterion (BIC) calculated for each specification (Clarke 2001). ${ }^{25}$ The BIC is used to compare the performance of nonnested models; the model with the lowest BIC best fits the observed patterns of confirmation outcomes. We also estimate a seventeenth model that tests for the impact of divided government on confirmation failure rates.

Raftery (1995) provides a scheme for interpreting differences in the BIC scores. Differences over 10 points indicate "very strong" evidence in support of the model with the lower BIC score. A 6-10 point difference indicates "strong" support for the model with the lower BIC score. A 2-5 point difference suggests "positive" support, and less than a 2-point difference implies "weak" support for the model with the lower BIC score. We use robust standard errors, clustering on the Congress number, for each of the estimations.

\section{Results}

Table 4 displays the parameter estimates for the 16 nonnested logit models predicting the likelihood that a

\footnotetext{
${ }^{24} \mathrm{ABA}$ ratings for the $101^{\text {st }}-109^{\text {th }}$ Congresses are drawn from http://www.abanet.org/scfedjud/ratings.html. ABA ratings for the previous Congresses were graciously provided by Shelly Goldman.

${ }^{25} \mathrm{BIC}$ scores are essentially goodness-of-fit values that allow for the comparison of nonnested models with or without different numbers of parameters. BIC scores are adjusted (or "penalized") by the number of estimated parameters and the sample size. On the use of BIC scores in political science research, see Clarke (2001). A related measure is the Akaike Information Criterion (AIC) measure, which has a different penalty calculation. However, because the number of degrees of freedom and number of observations are the same across all specifications, these two measures will produce the same differences between models. Therefore, we only report the BIC in the tables. Similar rankings result if we compare the models in terms of pseudo- $\mathrm{R}^{2}$, proportional reduction in error, or percent correctly predicted.
} 
TABLE 2A Summary Statistics, U.S. Courts of Appeals Nominations

\begin{tabular}{lcccc}
\hline Variable & Mean & Std. Dev. & Min & Max \\
\hline Confirmation rejection, 1975-2006 $(\mathrm{N}=367)$ & .27 & .45 & 0 & 1 \\
Confirmation rejection, 1975-1988 $(\mathrm{N}=143)$ & .09 & .29 & 0 & 1 \\
Confirmation rejection, 1989-2006 $(\mathrm{N}=224)$ & .39 & .49 & 0 & 1 \\
Median voter gridlock interval & .53 & .13 & .28 & .71 \\
Majority party gridlock interval & .65 & .24 & .28 & .98 \\
Filibuster gridlock interval & .70 & .16 & .38 & .89 \\
Blue slip gridlock interval & .78 & .24 & .28 & 1.51 \\
Committee gridlock interval & .58 & .17 & .29 & .94 \\
Filibuster and blue slip gridlock interval & .84 & .20 & .38 & 1.51 \\
Majority party and blue slip gridlock interval & .84 & .24 & .28 & 1.51 \\
Majority party and filibuster gridlock interval & .75 & .18 & .38 & .98 \\
Majority party, blue slip, and filibuster interval & .87 & .20 & .38 & 1.51 \\
Committee and majority party gridlock interval & .66 & .23 & .29 & .98 \\
Committee and filibuster gridlock interval & .70 & .16 & .38 & .94 \\
Committee and blue slip gridlock interval & .79 & .24 & .27 & 1.51 \\
Committee, filibuster and blue slip interval & .85 & .20 & .38 & 1.51 \\
Committee, filibuster, and maj. party interval & .75 & .18 & .38 & .98 \\
Committee, blue slip, and maj. party interval & .84 & .24 & .27 & 1.51 \\
Full model gridlock interval & .87 & .20 & .38 & 1.51 \\
Divided government & .50 & .50 & 0 & 1 \\
ABA-rated well-qualified judge (N = 366) & .64 & .48 & 0 & 1 \\
\hline
\end{tabular}

Note: $\mathrm{N}=367$ unless otherwise noted. Nominations to D.C. Circuit Court of Appeals are excluded.

TABLE 2B Summary Statistics, U.S. District Courts Nominations

\begin{tabular}{lcccc}
\hline Variable & Mean & Std. Dev. & Min & Max \\
\hline Confirmation rejection, 1975-2006 $(\mathrm{N}=1,364)$ & .16 & .36 & 0 & 1 \\
Confirmation rejection, 1975-1988 $(\mathrm{N}=560)$ & .09 & .28 & 0 & 1 \\
Confirmation rejection, 1989-2006 $(\mathrm{N}=804)$ & .21 & .41 & 0 & 1 \\
Median voter gridlock interval & .52 & .14 & .28 & .71 \\
Majority party gridlock interval & .64 & .23 & .28 & .98 \\
Filibuster gridlock interval & .68 & .15 & .38 & .89 \\
Blue slip gridlock interval & .77 & .24 & .28 & 1.47 \\
Committee gridlock interval & .56 & .16 & .29 & .94 \\
Filibuster and blue slip gridlock interval & .83 & .20 & .38 & 1.47 \\
Majority party and blue slip gridlock interval & .82 & .24 & .28 & 1.47 \\
Majority party and filibuster gridlock interval & .73 & .18 & .38 & .98 \\
Majority party, blue slip, and filibuster interval & .85 & .20 & .38 & 1.47 \\
Committee and majority party gridlock interval & .65 & .22 & .29 & .98 \\
Committee and filibuster gridlock interval & .68 & .16 & .38 & .94 \\
Committee and blue slip gridlock interval & .78 & .24 & .27 & 1.47 \\
Committee, filibuster and blue slip interval & .83 & .20 & .38 & 1.47 \\
Committee, filibuster, and maj. party interval & .73 & .18 & .38 & .98 \\
Committee, blue slip, and maj. party interval & .82 & .23 & .27 & 1.47 \\
Full model gridlock interval & .85 & .20 & .38 & 1.47 \\
Divided government & .48 & .50 & 0 & 1 \\
\hline
\end{tabular}

Note: $\mathrm{N}=1,364$ unless otherwise noted. Nominations to D.C. District Court are excluded. 
TABle 3 Nominee Failure Rates by Congress

\begin{tabular}{lccccc}
\hline & \multicolumn{2}{c}{ U.S. Courts of Appeals } & & \multicolumn{2}{c}{ U.S. District Courts } \\
\cline { 2 - 3 } \cline { 5 - 6 } Congress & Failure Rate & Nominations $(\mathbf{N})$ & & Failure Rate & Nominations (N) \\
\hline $94(1975-76)$ & .10 & 10 & & .21 & 48 \\
$95(1977-78)$ & 0 & 12 & & .02 & 47 \\
$96(1979-80)$ & .09 & 44 & & .08 & 160 \\
$97(1981-82)$ & 0 & 17 & & .02 & 65 \\
$98(1983-84)$ & .17 & 12 & & .12 & 67 \\
$99(1985-86)$ & 0 & 28 & & .05 & 97 \\
$100(1987-88)$ & .30 & 20 & & .15 & 76 \\
$101(1989-90)$ & .06 & 16 & & .04 & 49 \\
$102(1991-92)$ & .35 & 29 & & .30 & 142 \\
$103(1993-94)$ & .16 & 19 & & .10 & 112 \\
$104(1995-96)$ & .39 & 18 & & .25 & 83 \\
$105(1997-98)$ & .28 & 25 & & .15 & 89 \\
$106(1999-2000)$ & .54 & 28 & & .29 & 79 \\
$107(2001-02)$ & .57 & 37 & & .16 & 94 \\
$108(2003-04)$ & .41 & 29 & & .11 & 94 \\
$109(2005-06)$ & .48 & 23 & & .48 & 62 \\
\hline
\end{tabular}

Sources: Legislative and Executive Calendars (Final edition) of the Senate Judiciary Committee $\left(94^{\text {th }}\right.$ $108^{\text {th }}$ Congresses); United States Department of Justice, Office of Legal Policy, http://www.usdoj.gov/ olp/judicialnominations109.htm (109 ${ }^{\text {th }}$ Congress).

nomination to the U.S. Courts of Appeals is rejected. The coefficients for each of the relevant gridlock intervals are statistically significant and in the expected positive direction. As the ideological distance between the pivots anchoring the gridlock intervals increases, the likelihood of rejection increases. We rank the models in ascending order of their BIC scores. The rank ordering of the models shows that the majority party plus filibuster gridlock model provides the best match to the data on confirmation outcomes over the period, with the filibuster gridlock model and the committee gridlock models providing the next best fits. ${ }^{26}$ The weakest-fitting models incorporate the preferences of home-state senators, while models combining the home-state senators with other pivots generate slightly better fits. The full model's BIC score places it at roughly the median location among all the models. ${ }^{27}$

\footnotetext{
${ }^{26}$ Note that the majority party-filibuster model and the majority party-committee-filibuster model produce identical results. Because the committee median is located anterior to the party and filibuster pivots, the gridlock intervals in the two models are identical.

${ }^{27}$ We also estimate each of the models controlling for nominee quality. The results are substantively the same as the results in Table 4 in terms of their BIC and other goodness-of-fit rankings. We also estimate models that include nominations to the D.C. Courts of Appeals, requiring us to drop the models in which the gridlock interval is anchored by one of the home-state senators. Once again the BIC rankings are the same as those reported in Table 4.
}

Given the range of BIC scores, the differences between most successive pairs of models are substantial. To be sure, there is a very slight substantive difference between a majority party plus filibuster model and a pure filibuster model; the BIC scores differ by less than three points. The four best-fitting models, however, provide a better match to the data than the median voter model. Moreover, the pure filibuster model outperforms the median voter model. Securing the support of the majority party median as well as that of the more extreme filibuster pivot is crucial to securing a vote on confirmation. The median voter is often the focus of spatial models of the appointments process, but his or her support is not sufficient to secure a floor vote. Importantly, four of the seven models incorporating the blue slip fare worse than the median voter model, while all models that incorporate the filibuster and almost all of the models that incorporate the majority party median fare better than the median voter model.

We also compare the models in terms of the substantive impact of the intervals on the probability that a nominee is rejected. In the far-right column of Table 4, we show how a change in the size of the interval affects the probability of rejection, varying the size of the interval from one standard deviation below to one standard deviation above its mean value. Changes in the majority party and filibuster interval have the greatest substantive effect 
TABLE 4 Comparison of Models: Likelihood of Rejection (U.S. Courts of Appeals, 1975-2006)

\begin{tabular}{|c|c|c|c|c|c|}
\hline Model & Constant & $\begin{array}{c}\text { Gridlock } \\
\text { Interval } \\
\end{array}$ & $\begin{array}{l}\text { Log } \\
\text { Lik. }\end{array}$ & BIC & $\begin{array}{c}\text { Change in Prob } \\
\text { of Rejection }\end{array}$ \\
\hline Majority party and filibuster & $\begin{array}{c}-5.81 \\
(1.39)\end{array}$ & $\begin{array}{c}6.11 \\
(1.58)\end{array}$ & -188.00 & -1779.45 & $+38 \%$ \\
\hline Majority party, filibuster, and committee & $\begin{array}{c}-5.81 \\
(1.39)\end{array}$ & $\begin{array}{c}6.11 \\
(1.58)\end{array}$ & -188.00 & -1779.45 & \\
\hline Filibuster and committee & $\begin{array}{r}-5.56 \\
(.95)\end{array}$ & $\begin{array}{c}6.22 \\
(1.10)\end{array}$ & -189.21 & -1777.04 & \\
\hline Filibuster & $\begin{array}{c}-5.83 \\
(1.13)\end{array}$ & $\begin{array}{c}6.63 \\
(1.38)\end{array}$ & -189.44 & -1776.57 & \\
\hline Committee & $\begin{array}{r}-3.24 \\
(.66)\end{array}$ & $\begin{array}{l}3.74 \\
(.82)\end{array}$ & -200.83 & -1753.79 & \\
\hline Majority party and committee & $\begin{array}{r}-2.92 \\
(.88)\end{array}$ & $\begin{array}{c}2.80 \\
(1.03)\end{array}$ & -202.03 & -1751.39 & \\
\hline Majority party & $\begin{array}{r}-2.82 \\
(.86)\end{array}$ & $\begin{array}{c}2.68 \\
(1.02)\end{array}$ & -202.13 & -1751.19 & \\
\hline "Full" model & $\begin{array}{r}-3.81 \\
(.81)\end{array}$ & $\begin{array}{l}3.14 \\
(.89)\end{array}$ & -203.23 & -1748.99 & $+24 \%$ \\
\hline Majority party, blue slip, and filibuster & $\begin{array}{r}-3.74 \\
\quad(.82)\end{array}$ & $\begin{array}{l}3.06 \\
(.90)\end{array}$ & -203.61 & -1748.25 & \\
\hline Filibuster, blue slip, and committee & $\begin{array}{r}-3.39 \\
(.64)\end{array}$ & $\begin{array}{l}2.77 \\
(.75)\end{array}$ & -204.82 & -1745.82 & \\
\hline Filibuster and blue slip & $\begin{array}{r}-3.34 \\
\quad(.61)\end{array}$ & $\begin{array}{l}2.73 \\
(.73)\end{array}$ & -205.16 & -1745.13 & \\
\hline Divided government & $\begin{array}{r}-1.56 \\
(.48)\end{array}$ & $\begin{array}{l}1.03 \\
(.54)\end{array}$ & -205.76 & -1743.94 & \\
\hline Median voter & $\begin{array}{r}-3.14 \\
\quad(.90)\end{array}$ & $\begin{array}{c}3.92 \\
(1.50)\end{array}$ & -206.68 & -1742.10 & $+20 \%$ \\
\hline Majority party, blue slip, and committee & $\begin{array}{r}-2.38 \\
(.91)\end{array}$ & $\begin{array}{c}1.62 \\
(1.01)\end{array}$ & -210.09 & -1735.29 & \\
\hline Majority party and blue slip & $\begin{array}{r}-2.32 \\
\quad(.92)\end{array}$ & $\begin{array}{c}1.57 \\
(1.02)\end{array}$ & -210.34 & -1734.78 & \\
\hline Blue slip and committee & $\begin{array}{r}-2.20 \\
\quad(.73)\end{array}$ & $\begin{array}{l}1.51 \\
(.88)\end{array}$ & -210.44 & -1734.57 & \\
\hline Blue slip & $\begin{array}{r}-1.92 \\
\quad(.60)\end{array}$ & $\begin{array}{l}1.19 \\
(.74)\end{array}$ & -212.07 & -1731.31 & $+11 \%$ \\
\hline
\end{tabular}

Notes: $\mathrm{N}=$ 367. Parameter estimates generated via Stata 9.2's logit routine. We report robust standard errors clustering on the Congress number. The gridlock intervals are significant at $\mathrm{p}<.10$ or better (one-tailed tests) for all models; the constant terms are significant at $\mathrm{p}<.001$. Change in the probability of rejection is calculated for selected models via Stata 9.2's $m f x$ routine. The table shows the difference in the probability of rejection as the value of the interval moves from one standard deviation below to one standard deviation above the mean value of the interval.

on the likelihood of rejection. When this gridlock interval is one standard deviation above the mean, the probability of failure is $47 \%$. When it is one standard deviation below the mean, the probability is about $9 \%$, a $38 \%$ gap. In comparison, increases in the size of the median interval raise the chances of rejection by $20 \%$, while expansion of the gridlock interval formed between the two most extreme of all the pivots increases the rejection rate by $24 \%$. In contrast, considering only the views of homestate senators and the president, expansion of the blue slip interval increases the likelihood of rejection by only $11 \%$. 
TABLE 5 Comparison of Models: Likelihood of Rejection (U.S. Courts of Appeals, 1975-88)

\begin{tabular}{|c|c|c|c|c|}
\hline Model & Constant & $\begin{array}{c}\text { Gridlock } \\
\text { Interval }\end{array}$ & $\begin{array}{l}\text { Log } \\
\text { Lik. }\end{array}$ & BIC \\
\hline Divided government & $\begin{array}{r}-2.88 \\
(.54)\end{array}$ & $\begin{array}{l}1.69 \\
(.66)\end{array}$ & -39.75 & -620.26 \\
\hline Majority party & $\begin{array}{r}-4.35 \\
(1.44)\end{array}$ & $\begin{array}{c}3.59 \\
(1.92)\end{array}$ & -40.58 & -618.60 \\
\hline Majority party and committee & $\begin{array}{r}-4.34 \\
(1.55)\end{array}$ & $\begin{array}{c}3.51 \\
(2.10)\end{array}$ & -40.81 & -618.14 \\
\hline Majority party and filibuster & $\begin{array}{r}-4.76 \\
(1.91)\end{array}$ & $\begin{array}{c}3.86 \\
(2.63)\end{array}$ & -41.27 & -617.23 \\
\hline Majority party, filibuster, and committee & $\begin{array}{r}-4.76 \\
(1.91)\end{array}$ & $\begin{array}{c}3.86 \\
(2.63)\end{array}$ & -41.27 & -617.23 \\
\hline Median voter & $\begin{array}{r}-4.25 \\
(1.91)\end{array}$ & $\begin{array}{c}3.88 \\
(3.78)\end{array}$ & -42.22 & -615.32 \\
\hline Committee & $\begin{array}{r}-3.93 \\
(1.73)\end{array}$ & $\begin{array}{c}3.19 \\
(3.54)\end{array}$ & -42.57 & -614.63 \\
\hline Filibuster & $\begin{array}{r}-4.18 \\
(2.07)\end{array}$ & $\begin{array}{c}3.18 \\
(3.76)\end{array}$ & -42.65 & -614.46 \\
\hline Filibuster and committee & $\begin{array}{r}-4.18 \\
(2.07)\end{array}$ & $\begin{array}{c}3.18 \\
(3.76)\end{array}$ & -42.65 & -614.46 \\
\hline Majority party and blue slip & $\begin{array}{r}-2.74 \\
(1.08)\end{array}$ & $\begin{array}{c}0.57 \\
(1.78)\end{array}$ & -43.46 & -612.84 \\
\hline Majority party, blue slip, and committee & $\begin{array}{r}-2.71 \\
(1.05)\end{array}$ & $\begin{array}{c}0.54 \\
(1.75)\end{array}$ & -43.47 & -612.81 \\
\hline Majority party, blue slip, and filibuster & $\begin{array}{r}-2.73 \\
(1.28)\end{array}$ & $\begin{array}{c}.55 \\
(2.04)\end{array}$ & -43.49 & -612.78 \\
\hline "Full" model & $\begin{array}{r}-2.72 \\
(1.29)\end{array}$ & $\begin{array}{c}0.54 \\
(2.05)\end{array}$ & -43.49 & -612.78 \\
\hline Filibuster and blue slip & $\begin{array}{r}-2.27 \\
(1.03)\end{array}$ & $\begin{array}{r}-0.04 \\
(1.89)\end{array}$ & -43.56 & -612.64 \\
\hline Filibuster, blue slip, and committee & $\begin{array}{r}-2.27 \\
(1.03)\end{array}$ & $\begin{array}{c}-0.04 \\
(1.89)\end{array}$ & -43.56 & -612.64 \\
\hline Blue slip & $\begin{array}{r}-2.32 \\
(.86)\end{array}$ & $\begin{array}{c}0.02 \\
(1.69)\end{array}$ & -43.56 & -612.64 \\
\hline Blue slip and committee & $\begin{array}{r}-2.31 \\
(.82)\end{array}$ & $\begin{array}{c}0.01 \\
(1.66)\end{array}$ & -43.56 & -612.64 \\
\hline
\end{tabular}

Notes: $\mathrm{N}=143$. Parameter estimates generated via Stata 9.2's logit routine. We report robust standard errors clustering on the Congress number. The gridlock intervals for the five top models are significant at $\mathrm{p}<.10$ or better (one-tailed test), while the rest of the interval coefficients are not significant. The constant terms are significant at $\mathrm{p}<.05$ or better in all cases.

To examine whether nomination politics have changed over time, we separate the data into two time periods, from 1975 to 1988, taking us from Presidents Gerald Ford through Ronald Reagan, and from 1989 to 2006, taking us from George H. W. Bush through George W. Bush (Tables 5 and 6). Dividing the time series at Robert Bork's controversial 1989 nomination for the Supreme Court helps us to capture what some analysts designate as a watershed event in the Senate's treatment of judicial nominees (Martinek, Kemper, and Van Winkle 2002). In the early period, consent of the majority party remains consequential. To be sure, there is little substantive difference between a model capturing divided party control of the Senate and the White House and a model capturing the ideological distance between the president and the majority party median. Both models suggest that the majority 
TABLE 6 Comparison of Models: Likelihood of Rejection (U.S. Courts of Appeals, 1989-2006)

\begin{tabular}{|c|c|c|c|c|}
\hline Model & Constant & $\begin{array}{l}\text { Gridlock } \\
\text { Interval }\end{array}$ & Log Lik. & BIC \\
\hline Filibuster and committee & $\begin{array}{r}-4.12 \\
(.81)\end{array}$ & $\begin{array}{l}4.63 \\
(.90)\end{array}$ & -142.89 & -915.61 \\
\hline Filibuster & $\begin{array}{r}-4.38 \\
(1.00)\end{array}$ & $\begin{array}{c}5.00 \\
(1.19)\end{array}$ & -143.13 & -915.13 \\
\hline Majority party and filibuster & $\begin{array}{r}-4.52 \\
(1.20)\end{array}$ & $\begin{array}{c}4.76 \\
(1.32)\end{array}$ & -143.72 & -913.95 \\
\hline Majority party, filibuster, and committee & $\begin{array}{r}-4.52 \\
(1.20)\end{array}$ & $\begin{array}{c}4.76 \\
(1.32)\end{array}$ & -143.72 & -913.95 \\
\hline Filibuster, blue slip, and committee & $\begin{array}{r}-2.43 \\
(.92)\end{array}$ & $\begin{array}{c}2.16 \\
(1.02)\end{array}$ & -145.99 & -909.42 \\
\hline Filibuster and blue slip & $\begin{array}{r}-2.40 \\
(.90)\end{array}$ & $\begin{array}{c}2.13 \\
(1.02)\end{array}$ & -146.07 & -909.24 \\
\hline "Full" model & $\begin{array}{c}-2.62 \\
(1.14)\end{array}$ & $\begin{array}{c}2.29 \\
(1.20)\end{array}$ & -146.25 & -908.88 \\
\hline Committee & $\begin{array}{r}-1.84 \\
(.63)\end{array}$ & $\begin{array}{l}2.14 \\
(.80)\end{array}$ & -146.36 & -908.67 \\
\hline Majority party, blue slip, and filibuster & $\begin{array}{c}-2.52 \\
(1.10)\end{array}$ & $\begin{array}{c}2.18 \\
(1.17)\end{array}$ & -146.46 & -908.48 \\
\hline Blue slip and committee & $\begin{array}{r}-1.32 \\
(.87)\end{array}$ & $\begin{array}{c}1.02 \\
(1.01)\end{array}$ & -148.15 & -905.08 \\
\hline Majority party & $\begin{array}{r}-1.21 \\
(.72)\end{array}$ & $\begin{array}{l}1.01 \\
(.93)\end{array}$ & -148.38 & -904.63 \\
\hline Majority party and committee & $\begin{array}{r}-1.26 \\
(.77)\end{array}$ & $\begin{array}{l}1.07 \\
(.99)\end{array}$ & -148.39 & -904.61 \\
\hline Blue slip & $\begin{array}{r}-1.11 \\
(.72)\end{array}$ & $\begin{array}{l}0.80 \\
(.89)\end{array}$ & -148.68 & -904.03 \\
\hline Median voter & $\begin{array}{r}-1.40 \\
(.93)\end{array}$ & $\begin{array}{c}1.64 \\
(1.64)\end{array}$ & -148.69 & -904.00 \\
\hline Majority party, blue slip, and committee & $\begin{array}{r}-1.11 \\
(.99)\end{array}$ & $\begin{array}{c}.72 \\
(1.08)\end{array}$ & -148.98 & -903.42 \\
\hline Majority party and blue slip & $\begin{array}{r}-1.06 \\
(.95)\end{array}$ & $\begin{array}{c}.67 \\
(1.04)\end{array}$ & -149.04 & -903.31 \\
\hline Divided government & $\begin{array}{r}-.55 \\
(.32)\end{array}$ & $\begin{array}{c}.14 \\
(.42)\end{array}$ & -149.53 & -902.33 \\
\hline
\end{tabular}

Notes: $\mathrm{N}=224$. Parameter estimates generated via Stata 9.2's logit routine. We report robust standard errors clustering on the Congress number. The gridlock intervals for the nine top models are significant at $p<.10$ or better (one-tailed test); the constant terms are significant at $\mathrm{p}<.10$ or better in the top 14 cases plus the divided government model (one-tailed test).

party's control of the executive session agenda directly affects the likelihood of confirmation, with majority parties even in this earlier period unlikely to give a free pass to the president in placing new appointees on the bench. In addition, although the impact of the filibuster pivot is slightly diminished in the early period, almost all of the models incorporating the filibuster pivot outperform the median voter model. Although manifest filibusters are a new feature of appellate court nominations, the threat of a filibuster seems to have been consequential in the earlier period. The several nominations subject to cloture votes in this era-for example, Stephen Breyer's nomination to the $1^{\text {st }}$ Circuit Court of Appeals in 1980-attest to the threat of filibusters in this period.

For the period after 1988, the impact of the filibuster pivot is more pronounced (Table 6). All but one of the models incorporating the filibuster as the most extreme pivot outperform a model in which the filibuster is not modeled. And again, each of the models incorporating the filibuster pivot and almost all of the models based 
TABLE 7 Comparison of Models: Likelihood of Rejection (U.S. District Courts, 1975-2006)

\begin{tabular}{|c|c|c|c|c|}
\hline Model & Constant & $\begin{array}{c}\text { Gridlock } \\
\text { Interval }\end{array}$ & Log Lik. & BIC \\
\hline Majority party and filibuster & $\begin{array}{r}-3.85 \\
(.54)\end{array}$ & $\begin{array}{l}2.87 \\
(.77)\end{array}$ & -574.26 & -8682.65 \\
\hline Majority party, filibuster, and committee & $\begin{array}{r}-3.85 \\
(.54)\end{array}$ & $\begin{array}{l}2.87 \\
(.77)\end{array}$ & -574.26 & -8682.65 \\
\hline "Full" model & $\begin{array}{r}-3.73 \\
(.47)\end{array}$ & $\begin{array}{l}2.33 \\
(.54)\end{array}$ & -577.17 & -8676.83 \\
\hline Majority party, blue slip, and filibuster & $\begin{array}{r}-3.71 \\
(.45)\end{array}$ & $\begin{array}{l}2.31 \\
(.53)\end{array}$ & -577.20 & -8676.75 \\
\hline Filibuster & $\begin{array}{r}-3.82 \\
(.73)\end{array}$ & $\begin{array}{c}3.06 \\
(1.11)\end{array}$ & -577.39 & -8676.38 \\
\hline Filibuster and blue slip & $\begin{array}{r}-3.55 \\
(.51)\end{array}$ & $\begin{array}{l}2.19 \\
(.59)\end{array}$ & -578.14 & -8674.87 \\
\hline Filibuster, blue slip, and committee & $\begin{array}{r}-3.52 \\
(.51)\end{array}$ & $\begin{array}{l}2.15 \\
(.59)\end{array}$ & -578.62 & -8673.92 \\
\hline Filibuster and committee & $\begin{array}{r}-3.64 \\
(.70)\end{array}$ & $\begin{array}{c}2.80 \\
(1.06)\end{array}$ & -578.65 & -8673.85 \\
\hline Majority party, blue slip, and committee & $\begin{array}{r}-3.15 \\
(.34)\end{array}$ & $\begin{array}{l}1.73 \\
(.29)\end{array}$ & -581.39 & -8668.37 \\
\hline Majority party and blue slip & $\begin{array}{r}-3.12 \\
(.36)\end{array}$ & $\begin{array}{l}1.70 \\
(.30)\end{array}$ & -581.55 & -8668.05 \\
\hline Divided government & $\begin{array}{r}-2.08 \\
(.38)\end{array}$ & $\begin{array}{c}.74 \\
(.42)\end{array}$ & -582.20 & -8666.77 \\
\hline Blue slip & $\begin{array}{r}-2.88 \\
(.34)\end{array}$ & $\begin{array}{l}1.52 \\
(.31)\end{array}$ & -583.07 & -8665.03 \\
\hline Blue slip and committee & $\begin{array}{r}-2.89 \\
(.34)\end{array}$ & $\begin{array}{l}1.50 \\
(.31)\end{array}$ & -583.58 & -8664.00 \\
\hline Majority party and committee & $\begin{array}{r}-2.67 \\
(.67)\end{array}$ & $\begin{array}{l}1.49 \\
(.83)\end{array}$ & -584.80 & -8661.55 \\
\hline Majority party & $\begin{array}{r}-2.60 \\
(.67)\end{array}$ & $\begin{array}{l}1.40 \\
(.83)\end{array}$ & -585.14 & -8660.87 \\
\hline Median voter & $\begin{array}{r}-2.75 \\
(.79)\end{array}$ & $\begin{array}{c}2.01 \\
(1.30)\end{array}$ & -588.22 & -8654.72 \\
\hline Committee & $\begin{array}{r}-2.48 \\
(.64)\end{array}$ & $\begin{array}{l}1.40 \\
(.96)\end{array}$ & -589.53 & -8652.09 \\
\hline
\end{tabular}

Notes: $\mathrm{N}=1,364$. Parameter estimates generated via Stata 9.2's logit routine. We report robust standard errors clustering on the Congress number. The gridlock intervals are significant at $\mathrm{p}<.10$ or better (one-tailed tests) for all models; the constant terms are all significant at $\mathrm{p}<.001$.

on the majority party median provide a better fit to the data than do models anchored by the chamber median. Although support of the median is necessary for a nomination to be confirmed once it reaches an up-or-down vote, nominees unable to avoid a filibuster and unable to secure the consent of the majority party median will have little chance of making it to an up-or-down vote on the Senate floor. In contrast, as in the earlier period, the blocking authority of even the most extreme home-state senators is quite limited, as the blue slip appears to confer informal—but imperfect—veto rights for the home-state senators. ${ }^{28}$

The forces that shape appellate court confirmation outcomes also appear to affect the district court outcomes. As shown in Table 7, the best-fitting model is again based

\footnotetext{
${ }^{28}$ As indicated in Tables 5-6 and 8-9, not all of the gridlock interval coefficients reach statistical significance. We are clustering the standard errors on the Congress number, and with so few clusters in the shorter time periods statistical significance is much harder to achieve.
} 
on the majority party plus filibuster pivots. Similar to the appellate court nominees, models incorporating the preferences of an extreme filibuster pivot outperform the other models. All of the models including a filibuster pivot provide a better match to the data on confirmation outcomes than does a model that accounts solely for the preferences of the president and the chamber median. Indeed, 14 of the models (in addition to the divided government model) outperform the median voter model, meaning that the floor median model outperforms only the basic committee model. To be sure, district court nominations succeed at higher rates than do appellate court nominations, but it does appear that senators with blocking authority do not give district court nominees a free pass to confirmation. Given the polarization of the parties and with that the widening of the gridlock intervals including the filibuster, the ability of the president to move the court location off the status quo is constrained, even for the less visible trial court vacancies.

Dividing the data into two time periods offers some nuance to these findings. As shown in Table 8 , for the period before 1989, the views of the filibuster pivot are of diminished importance; only two of the gridlock intervals anchored by a filibuster pivot provide a better fit than the median voter model. Overall, still, the views of the majority party - even the simple fact of divided party control-appear to be consequential for explaining the likelihood of confirmation failure. In contrast (Table 9), for the period after 1988, the dynamics of confirmation failure differ markedly. Each of the models anchored by a home-state senator outperforms the median voter model, as well as the majority party, filibuster, and majority party plus filibuster models. Unlike appointment politics for the more salient Courts of Appeals, decisions about whether to confirm trial court nominees appear to be influenced strongly by the preferences of the home-state senators. The more extreme are those senators' preferences, the greater the chance of failure.

\section{Discussion}

The construction of 16 spatial models affords a valuable opportunity to understand how Senate institutions affect the course of judicial selection. Because chamber and committee rules and practices distribute leverage over the confirmation process to multiple Senate players, the power to block appointments is theoretically held by multiple pivots. Ideological differences between the president and these key players are thus potentially consequential for the fate of judicial nominees, as such differences en- courage senators to exploit the rules of the game in an effort to block nominees they oppose. The results here suggest that for nominations to the federal appeals and district courts, the majority party median and the senator(s) capable of sustaining a filibuster appear to be the most important players in the process over the past three decades. Although the support of all of the pivots appears to be critical for confirmation, Senate decisions seem disproportionately affected by the preferences of the majority party and potential filibustering senators. Importantly, this finding is not simply an artifact of increased partisan differences over nominees in recent years; the results are sustained in both the 1970s and 1980s, as well as in more recent decades.

Why might the preferences of the majority party median and the filibuster pivot matter more than the preferences of other Senate players? Clearly the impact of the filibuster pivot arises from the ability of a minority of senators to withhold consent for confirmation and to block cloture efforts intended to secure up-or-down votes on nominees. Although manifest filibusters may be a feature of only the most recent Congresses, the need to accommodate the preferences of a supermajority of the Senate is made clear in the top ranking of the models that incorporate the filibuster pivots.

The strong fit of the models incorporating the majority party median is also suggestive of the types of accommodations that presidents make to secure confirmation. It may be that there is some strong element of presidential deference to senators of his party in selecting court nominees. This seems to be especially true in the period 1975-88, when divided government and majority party models perform equally well. But the results in the article clearly show that divided government is only part of the story. For the entire time period, and especially in the post-Reagan years, gridlock intervals do a better job of explaining the pattern of rejections in the data. Moreover, the degree of dissension between the president and key senators - not just the mere presence of a divided government-is important for explaining confirmation outcomes. ${ }^{29}$ Given the top ranking of the models incorporating either or both the filibuster and majority party pivots and given the rise in confirmation failure for both levels of the bench, it seems reasonable to conclude that presidents have been increasingly unsuccessful in selecting nominees sufficiently moderate to attract the support of opposition party senators. Increasing ideological

\footnotetext{
${ }^{29}$ The majority party gridlock interval and the variable denoting divided government capture different concepts, even if they are highly correlated.
} 
TABLE 8 Comparison of Models: Likelihood of Rejection (U.S. District Courts, 1975-88)

\begin{tabular}{|c|c|c|c|c|}
\hline Model & Constant & $\begin{array}{c}\text { Gridlock } \\
\text { Interval }\end{array}$ & Log Lik. & BIC \\
\hline Divided government & $\begin{array}{r}-2.72 \\
(.25)\end{array}$ & $\begin{array}{l}1.13 \\
(.30)\end{array}$ & -157.66 & -3215.67 \\
\hline Majority party & $\begin{array}{r}-3.51 \\
(.49)\end{array}$ & $\begin{array}{l}2.07 \\
(.68)\end{array}$ & -160.23 & -3210.53 \\
\hline Majority party and committee & $\begin{array}{r}-3.49 \\
(.49)\end{array}$ & $\begin{array}{l}1.99 \\
(.70)\end{array}$ & -160.58 & -3209.83 \\
\hline Majority party and filibuster & $\begin{array}{r}-3.70 \\
(.58)\end{array}$ & $\begin{array}{l}2.15 \\
(.78)\end{array}$ & -161.17 & -3208.65 \\
\hline Majority party, filibuster, and committee & $\begin{array}{r}-3.70 \\
(.58)\end{array}$ & $\begin{array}{l}2.15 \\
(.78)\end{array}$ & -161.17 & -3208.65 \\
\hline Median voter & $\begin{array}{r}-3.43 \\
(.57)\end{array}$ & $\begin{array}{c}2.15 \\
(1.18)\end{array}$ & -162.22 & -3206.55 \\
\hline Filibuster & $\begin{array}{r}-3.51 \\
(.71)\end{array}$ & $\begin{array}{c}1.96 \\
(1.27)\end{array}$ & -162.50 & -3205.98 \\
\hline Filibuster and committee & $\begin{array}{r}-3.51 \\
(.71)\end{array}$ & $\begin{array}{c}1.96 \\
(1.27)\end{array}$ & -162.50 & -3205.98 \\
\hline Majority party, blue slip, and filibuster & $\begin{array}{r}-3.22 \\
(.57)\end{array}$ & $\begin{array}{l}1.11 \\
(.71)\end{array}$ & -162.67 & -3205.65 \\
\hline Committee & $\begin{array}{r}-3.24 \\
(.57)\end{array}$ & $\begin{array}{c}1.73 \\
(1.23)\end{array}$ & -162.67 & -3205.64 \\
\hline "Full" model & $\begin{array}{r}-3.22 \\
(.57)\end{array}$ & $\begin{array}{l}1.10 \\
(.72)\end{array}$ & -162.70 & -3205.60 \\
\hline Majority party and blue slip & $\begin{array}{r}-3.11 \\
(.51)\end{array}$ & $\begin{array}{l}0.99 \\
(.67)\end{array}$ & -162.70 & -3205.59 \\
\hline Majority party, blue slip, and committee & $\begin{array}{r}-3.04 \\
(.52)\end{array}$ & $\begin{array}{l}0.90 \\
(.69)\end{array}$ & -162.88 & -3205.23 \\
\hline Filibuster and blue slip & $\begin{array}{r}-3.13 \\
(.62)\end{array}$ & $\begin{array}{l}1.00 \\
(.80)\end{array}$ & -162.89 & -3205.21 \\
\hline Filibuster, blue slip, and committee & $\begin{array}{r}-3.13 \\
(.62)\end{array}$ & $\begin{array}{l}1.00 \\
(.80)\end{array}$ & -162.89 & -3205.21 \\
\hline Blue slip & $\begin{array}{r}-2.95 \\
(.56)\end{array}$ & $\begin{array}{l}0.80 \\
(.74)\end{array}$ & -163.07 & -3204.84 \\
\hline Blue slip and committee & $\begin{array}{r}-2.88 \\
(.56)\end{array}$ & $\begin{array}{l}0.71 \\
(.76)\end{array}$ & -163.22 & -3204.55 \\
\hline
\end{tabular}

Notes: $\mathrm{N}=560$. Parameter estimates generated via Stata 9.2's logit routine. We report robust standard errors clustering on the Congress number. The gridlock intervals for the top 13 models are significant at $\mathrm{p}<.10$ or better (one-tailed test); the constant terms are significant at $\mathrm{p}<.001$ in all cases.

differences between the parties clearly exacerbate the challenge of selecting confirmable nominees.

The results also have implications for our understanding of constraints on the president's ability to move the bench towards his preferences. Jacobi (2005) argues that senatorial courtesy (protected through the blue slip) can impose a check on the president's appointment power by shaping the range of nominees that the Senate will con- firm. Our results lend some caution to Jacobi's conclusion. When we evaluate the fit of the models for appointments to the Courts of Appeals, the gridlock intervals incorporating home-state senators' preferences always perform worse than the pure forms of the committee, filibuster, and majority party models. This suggests that the blue slip does not confer a reliable veto on home-state senators when the Senate considers salient appellate court 
TABLE 9 Comparison of Models: Likelihood of Rejection (U.S. District Courts, 1989-2006)

\begin{tabular}{|c|c|c|c|c|}
\hline Model & Constant & $\begin{array}{c}\text { Gridlock } \\
\text { Interval }\end{array}$ & Log Lik. & BIC \\
\hline Filibuster and blue slip & $\begin{array}{r}-3.04 \\
(.77)\end{array}$ & $\begin{array}{l}1.89 \\
(.84)\end{array}$ & -403.75 & -4557.56 \\
\hline Filibuster, blue slip, and committee & $\begin{array}{r}-2.97 \\
(.79)\end{array}$ & $\begin{array}{l}1.80 \\
(.86)\end{array}$ & -404.33 & -4556.40 \\
\hline Blue slip & $\begin{array}{r}-2.44 \\
\quad(.47)\end{array}$ & $\begin{array}{l}1.34 \\
(.40)\end{array}$ & -404.46 & -4556.13 \\
\hline Majority party, blue slip, and filibuster & $\begin{array}{r}-3.12 \\
(.72)\end{array}$ & $\begin{array}{l}1.91 \\
(.77)\end{array}$ & -404.47 & -4556.11 \\
\hline "Full" model & $\begin{array}{r}-3.15 \\
\quad(.76)\end{array}$ & $\begin{array}{l}1.94 \\
(.80)\end{array}$ & -404.53 & -4556.00 \\
\hline Blue slip and committee & $\begin{array}{r}-2.39 \\
(.53)\end{array}$ & $\begin{array}{l}1.25 \\
(.48)\end{array}$ & -405.69 & -4553.68 \\
\hline Majority party, blue slip, and committee & $\begin{array}{r}-2.53 \\
(.64)\end{array}$ & $\begin{array}{l}1.32 \\
(.55)\end{array}$ & -406.11 & -4552.85 \\
\hline Majority party and blue slip & $\begin{array}{r}-2.46 \\
(.64)\end{array}$ & $\begin{array}{l}1.24 \\
(.54)\end{array}$ & -406.35 & -4552.36 \\
\hline Majority party and filibuster & $\begin{array}{r}-2.68 \\
(.85)\end{array}$ & $\begin{array}{c}1.63 \\
(1.07)\end{array}$ & -407.92 & -4549.22 \\
\hline Majority party, filibuster, and committee & $\begin{array}{r}-2.68 \\
(.85)\end{array}$ & $\begin{array}{c}1.63 \\
(1.07)\end{array}$ & -407.92 & -4549.22 \\
\hline Filibuster & $\begin{array}{c}-2.57 \\
(1.26)\end{array}$ & $\begin{array}{c}1.63 \\
(1.73)\end{array}$ & -408.35 & -4548.37 \\
\hline Filibuster and committee & $\begin{array}{c}-2.35 \\
(1.21)\end{array}$ & $\begin{array}{c}1.33 \\
(1.62)\end{array}$ & -408.91 & -4547.24 \\
\hline Median voter & $\begin{array}{c}-1.75 \\
(1.16)\end{array}$ & $\begin{array}{c}0.74 \\
(1.86)\end{array}$ & -410.19 & -4544.68 \\
\hline Divided government & $\begin{array}{r}-1.45 \\
(.57)\end{array}$ & $\begin{array}{l}.16 \\
(.61)\end{array}$ & -410.40 & -4544.27 \\
\hline Majority party and committee & $\begin{array}{l}-1.60 \\
(1.05)\end{array}$ & $\begin{array}{c}0.35 \\
(1.24)\end{array}$ & -410.41 & -4544.24 \\
\hline Majority party & $\begin{array}{r}-1.56 \\
(.99)\end{array}$ & $\begin{array}{c}0.31 \\
(1.17)\end{array}$ & -410.44 & -4544.18 \\
\hline Committee & $\begin{array}{c}-1.43 \\
(1.00)\end{array}$ & $\begin{array}{c}0.14 \\
(1.38)\end{array}$ & -410.74 & -4543.59 \\
\hline
\end{tabular}

Notes: $\mathrm{N}=804$. Parameter estimates generated via Stata 9.2's logit routine. We report robust standard errors clustering on the Congress number. The gridlock intervals for the 10 top models are significant at $\mathrm{p}<.10$ or better (one-tailed test); the constant terms are significant at $\mathrm{p}<.10$ or better in all cases (one-tailed test).

nominees, at least as compared to the blocking power of dissenters within the Judiciary panel, the majority party, and the minority empowered by Rule 22 .

Once again, the limits of highlighting a single institutional veto- to the exclusion of other pivots-are apparent. The results suggest that the blue slip is better conceived as an advisory or informational tool for the committee when it considers appellate court nomi- nations, rather than a practice that extends an absolute veto. The greater salience of such appointments to the political parties reduces the chambers' willingness to respect objections from home-state senators, particularly when they come from the opposition party. Objections to a nominee from a home-state senator signal to other senators and the president that a nominee may be in trouble, but such views reliably hold force only if they are held by 
other actors whose procedural prerogatives are formally protected in Senate rules.

In contrast, Jacobi's findings about the importance of the blue slip seem to be on the mark in the context of recent appointments to the less salient federal trial courts: the views of the more extreme home-state senator are consequential for the fate of judicial nominees, as our results suggest that all of the models incorporating the preferences of the home-state senators perform better than the pure forms of the committee, party, and filibuster models. In part because the decisions of trial courts are less consequential for the shape of public policy than are the decisions of the Courts of Appeals, appointments to the trial courts provide valuable patronage opportunities to senators. Deference to the views of home-state senators should thus be more pronounced for trial than for appellate appointments. The heightened impact of the preferences of home-state senators over the fate of district court nominees in the 1989-2006 time period likely reflects the frequency with which President George W. Bush nominated trial court judges who were unacceptable to the senators from states with Democratic Senate delegations.

\section{Conclusion}

Spatial models have produced new insights into the constraints imposed by the Senate on the president's appointment power. We contribute to these efforts in two ways. First, we have used spatial models of confirmation politics to take closer account of the array of institutional rules and practices that senators exploit to increase their influence over the makeup of the federal bench. Existing models largely focus on the power of the chamber's median voter or the filibuster pivot in constraining the president's ability to alter the composition of the federal courts. By studying competing pivots, we offer a theoretical portrait of the confirmation process that more closely resembles the institutional context in which appointees are considered by the Senate.

Second, our empirical findings confirm the importance of looking beyond the median voter to explain patterns in judicial selection, showing that the president's autonomy in shaping the federal bench is curtailed most strongly by the preferences of the Senate's majority party and by the veto rights of floor minorities under Rule 22 . In contrast, home-state senators-though given a privileged role in the Senate's review of district court nominees in recent years - may play more of an informational than a pivotal role in shaping Senate outcomes in most time periods. Our results demonstrate the value of consider- ing multiple pivots in modeling advice and consent, as the relative importance of these pivots changes over time. More broadly, our results reinforce the value of competing models and of using them to decipher critical patterns in American national politics.

\section{References}

Bailey, Michael, and Kelly Chang. 2003. "Extremists on the Court: The Inter-Institutional Politics of Supreme Court Appointments." Presented at the 2003 annual meeting of the American Political Science Association.

Binder, Sarah A., and Forrest Maltzman. 2002. "Senatorial Delay in Confirming Federal Judges, 1947-1998.” American Journal of Political Science 46(1): 190-99.

Caldeira, Gregory A., Marie Hojnacki, and John R. Wright. 2000. "The Lobbying Activities of Organized Interests in Federal Judicial Nominations." Journal of Politics 62(1): 51-69.

Caldeira, Gregory A., and John R. Wright. 1998. "Lobbying for Justice: Organized Interests Supreme Court Nominations, and the United States Senate." American Journal of Political Science 42(2): 499-523.

Cameron, Charles M., Albert D. Cover, and Jeffrey A. Segal. 1990. "Senate Voting on Supreme Court Nominees: A Neoinstitutional Model." American Political Science Review 84(2): 525-34.

Chang, Kelly H. 2001. "The President versus the Senate: Appointments in the American System of Separated Powers and the Federal Reserve." Journal of Law, Economics, \& Organization 17(2): 319-55.

Chase, Harold. 1972. Federal Judges: The Appointing Process. Minneapolis: University of Minnesota Press.

Chiou, Fang-Yi, and Lawrence S. Rothenberg. 2003. "When Pivotal Politics Meets Partisan Politics.” American Journal of Political Science 47(3): 503-22.

Clarke, Kevin A. 2001. "Testing Nonnested Models of International Relations: Reevaluating Realism." American Journal of Political Science 45(3): 724-44.

Cox, Gary W., and Mathew D. McCubbins. 2005. Setting the Agenda: Responsible Party Government in the U.S. House of Representatives. New York: Cambridge University Press.

Dewar, Helen. 2003. “Sarbanes, Mikulski Protest Virginia’s Appeals Nomination.” Washington Post, October 29, P. B01.

Epstein, Lee, Rene Lindstadt, Jeffrey A. Segal, and Chad Westerland. 2006. "The Changing Dynamics of Senate Voting on Supreme Court Nominees.” Journal of Politics 68(2): 296307.

Gerber, Elisabeth R. 1999. The Populist Paradox: Interest Group Influence and the Promise of Direct Legislation. Princeton, NJ: Princeton University Press.

Goldman, Sheldon. 1997. Picking Federal Judges. New Haven, CT: Yale University Press.

Hammond, Thomas H., Chris W. Bonneau, and Reginald S. Sheehan. 2005. Strategic Behavior and Policy Choice on the U.S. Supreme Court. Stanford, CA: Stanford University Press. 
Hammond, Thomas H., and Jeffrey S. Hill. 1993. "Deference or Preference? Explaining Senate Confirmation of Presidential Nominees to Administrative Agencies." Journal of Theoretical Politics 5(1): 23-59.

Jacobi, Tonja. 2005. “The Senatorial Courtesy Game: Explaining the Norm of Informal Vetoes in Advice and Consent Nominations." Legislative Studies Quarterly 30(2): 193-218.

Johnson, Timothy R., and Jason M. Roberts. 2005. "Pivotal Politics, Presidential Capital, and Supreme Court Nominations." Congress and the Presidency 32(1): 31-48.

Krehbiel, Keith. 1998. Pivotal Politics. Chicago: University of Chicago Press.

Krehbiel, Keith. 2007. "Supreme Court Appointments as a Move-the-Median Game." American Journal of Political Science 51(2): 231-40.

Lyons, Richard. 1979. "On Capitol Hill." Washington Post, September 26, p. A4.

Martinek, Wendy L., Mark Kemper, and Steven R. Van Winkle. 2002. "To Advise and Consent: The Senate and Lower Federal Court Nominations, 1977-98." Journal of Politics 64(2):33761.

McCarty, Nolan M., Keith T. Poole, and Howard Rosenthal. 1997. Income Redistribution and the Realignment of American Politics. Washington, DC: American Enterprise Institute.

McCarty, Nolan, Keith T. Poole, and Howard Rosenthal. 2006. Polarized America: The Dance of Ideology and Unequal Riches. Cambridge, MA: MIT Press.

Moraski, Bryon J., and Charles R. Shipan. 1999. "The Politics of Supreme Court Nominations." American Journal of Political Science 43(4): 1069-95.
Nokken, Timothy, and Brian Sala. 2000. "Confirmation Dynamics: Presidential Appointments to Independent Agencies." Journal of Theoretical Politics 12(1): 91-112.

Primo, David M. 2002. "Rethinking Political Bargaining: Policymaking with a Single Proposer." Journal of Law, Economics, \& Organization 18(2): 411-27.

Raftery, Adrian E. 1995. "Bayesian Model Selection in Social Research.” Sociological Methodology 25:111-63.

Rohde, David W., and Kenneth A. Shepsle. 2007. "Advising and Consenting in the 60-Vote Senate: Strategic Appointment to the Supreme Court." Journal of Politics 69(3): 664-77.

Romer, Thomas, and Howard Rosenthal. 1978. "Political Resource Allocation, Controlled Agendas, and the Status Quo." Public Choice 33(4): 27-43.

Ruckman, P. J. 1993. "The Supreme Court, Critical Nominations, and the Senate Confirmation Process." Journal of Politics 55(3): 793-805.

Shipan, Charles R., and Megan Shannon. 2003. "Delaying Justice(s): A Duration Model of Supreme Court Confirmations." American Journal of Political Science 47(4): 65468.

Smith, Steven S. 2005. "Parties and Leadership in the Senate." In The Legislative Branch, ed. Paul J. Quirk and Sarah A. Binder. New York: Oxford University Press, 255-78.

Snyder, Susan K., and Barry R. Weingast. 2000. "The American System of Shared Powers: The President, Congress, and the NLRB." Journal of Law, Economics, \& Organization 16(2): 269-305.

Stolberg, Sheryl Gay. 2004. "Democrats Issue Threat to Block Court Nominees.” New York Times, March 27, p. A1. 